\title{
Geochemical signatures of pervasive meteoric diagenesis of Early Miocene syn-rift carbonate platform, Red Sea, NW Saudi Arabia
}

\author{
Khalid AL-RAMADAN ${ }^{1, *}$ \\ 1 King Fahd University of Petroleum \& Minerals, Geosciences Department, 3126, P.O. Box 1400, Dhahran, Saudi Arabia
}

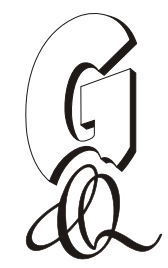

\begin{abstract}
Al-Ramadan, K., 2017. Geochemical signatures of pervasive meteoric diagenesis of Early Miocene syn-rift carbonate platform, Red Sea, NW Saudi Arabia. Geological Quarterly, 61 (1): 239-250, doi: 10.7306/gq.1334

Different diagenetic environments have been recognized in the Early Miocene carbonate platform of Musayr Formation in the Red Sea rift area. Early marine diagenesis includes micritisation that occurs as thin envelope around skeletal and non-skeletal grains in low-energy mud dominated facies and isopachous fibrous calcite in high-energy grain-dominated facies. Pervasive meteoric water diagenesis resulted in cementation of the carbonates by coarse-crystalline blocky-drusy calcite and meniscus cements. Depletion of oxygen (avg. $-9.08 \%$ ), carbon (avg. $-1.6 \%$ ) isotopes and trace elements concentrations (avg. values of Fe: 1387 ppm; Mn: 1444 ppm; Sr: 419 ppm; Na: 1194 ppm) in conjunction with negative correlation between $\mathrm{Mn}^{2+}$ and oxygen isotope data suggest variable degrees of fluid-rock interactions and pervasive meteoric diagenesis. The formation of meteoric diagenesis in the Musayr Formation can be explained by two subsequent mechanisms: (1) the presence of meteoric lenses during the time of deposition might have been associated with active freshwater input from the hinterland (NE) due to fall in the relative sea level; (2) later uplift episode during Plio-Pleistocene may have also contributed to the pervasive meteoric diagenetic alterations of the carbonates of the Musayr Formation. The first mechanism is supported by the cement stratigraphy where the blocky-drusy cements postdate the meniscus cement. The latter mechanism seems to have more pronounced effect on the alteration of Musayr carbonate sequence by observing the occurence of late cements such as blocky calcite in most of the samples. The impact of meteoric diagenesis on the studied samples suggest that dissolution is less severe than cementation, hence the visible porosity is very low. Understanding the timing of meteoric diagenesis provides useful information about the reservoir quality distribution in syn-rift carbonate sequences.
\end{abstract}

Key words: meteoric diagenesis, carbonate, stable isotopes, trace elements, Red Sea, Miocene.

\section{INTRODUCTION}

Constraining the distribution pattern of carbonate diagenesis has been a major research topic for decades. Many researchers (e.g., Bathurst, 1975; Allan and Matthews, 1982; Tucker, 1986; Bishop et al., 2014; Swart, 2015) have highlighted the sensitivity of metastable aragonite and high-Mg calcite (HMC) to the changes of pore water chemistry. The meteoric environment, in particular, plays a key role in the porosity development in carbonate reservoirs (e.g., Smalley et al., 1994; Bishop et al., 2014; Dickson and Kenter, 2014; Major, 2014). However, such studies have encountered many difficulties in recognizing the features and establish the impact of meteoric diagenesis from petrographic evidence solely. Therefore, recent studies (e.g., Melim et al., 2002; Heba et al., 2009; Swart, 2015) have suggested integration between petrographic data

\section{*E-mail: ramadank@kfupm.edu.sa}

Received: April 30, 2016; accepted: November 23, 2016; first published online: December 13, 2016 and stable oxygen and carbon isotopes, in conjunction with trace elemental analysis ( $\mathrm{Fe}, \mathrm{Mn}, \mathrm{Sr}, \mathrm{Na}$ ) of the bulk carbonate samples can be used to decipher the presence of meteoric diagenesis realm in ancient carbonate sequences.

The distribution and concentration of some trace elements (e.g., $\mathrm{Fe}, \mathrm{Mg}, \mathrm{Sr}, \mathrm{Mn}$ ) in carbonate sediments which are strongly influenced by depositional and diagenetic processes, are often used as environmental indicators. For example, $\mathrm{Sr}$ which is sensitive to depositional and diagenetic environments (Veizer and Demovic, 1974), has been used as a facies indicator showing increasing trend from backreef to forereef facies (Morrow and Mayers, 1978).

Several studies on carbon and oxygen isotopic signatures have been conducted, particularly on Holocene carbonate deposits (Gross, 1964; Land and Epstein, 1970; Allan and Matthews, 1977; Videtich, 1982; Melim et al., 2002). These studies have shown that the oxygen isotopic composition of these calcitised meteoric cements is invariant that may reflect a narrow range of both rainwater signature and temperature. Carbon isotope signatures are enriched with increasing depth.

This study aims at using the geochemical signatures to recognize the meteoric diagenesis and attempts to constrain its timing. The findings of this study can be used as analogue for other subsurface synrift carbonate sequence elsewhere. 


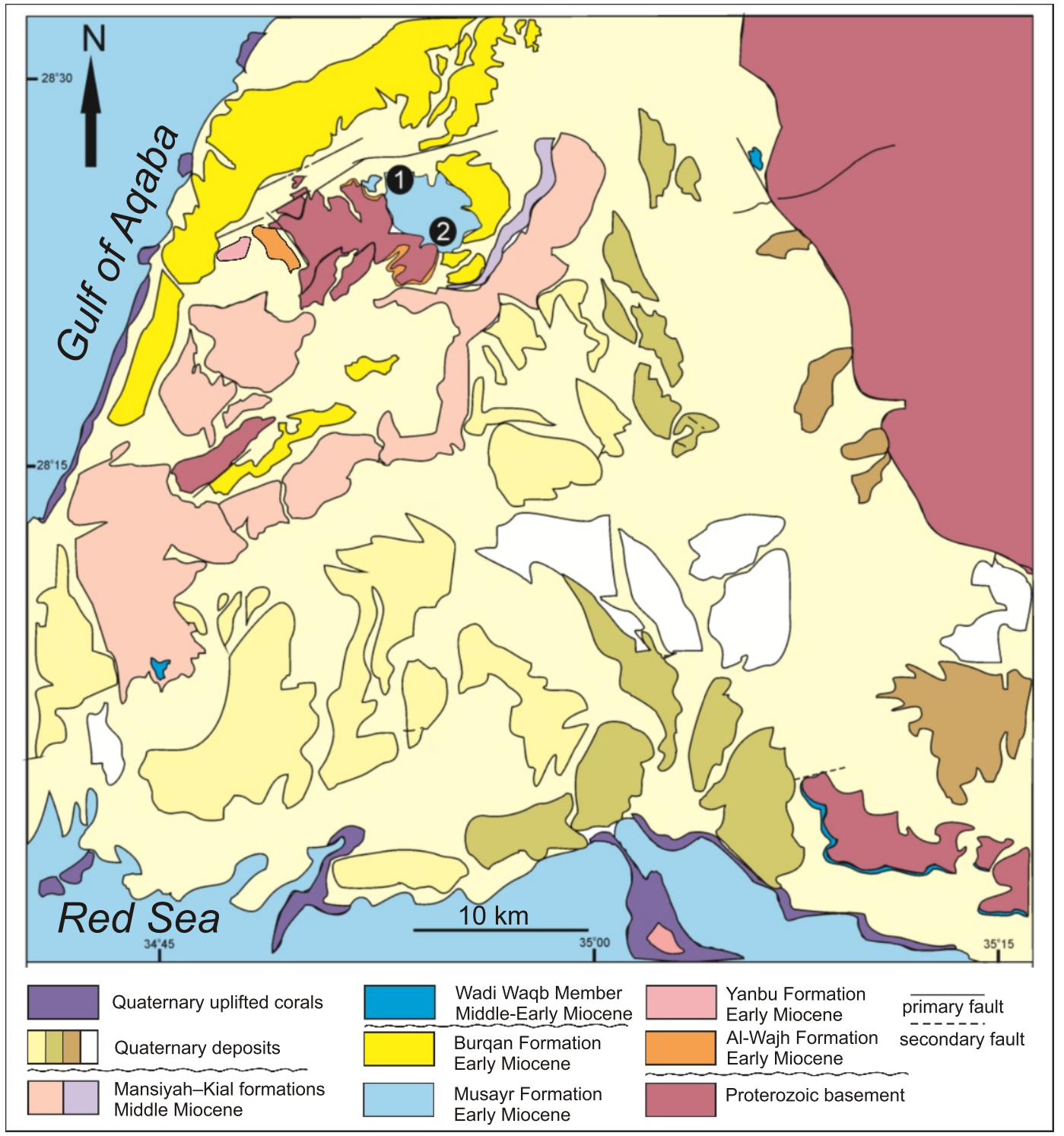

Fig. 1. Generalized geological map of the Midyan Peninsula (modified after Clark, 1986)

The Musayr Formation has been studied in two different locations as indicated in the map by number: 1 - Maqna locality, 2 - Wadi Al-Hamd locality

\section{STRATIGRAPHIC FRAMEWORK SETTINGS}

The studied carbonate platform successions of Musayr Formation are well exposed in the study areas of Midyan Peninsula (Fig. 1). Midyan Peninsula is located within an active tectonic region that is greatly influenced by Late Oligocene maritime Red Sea rifting and Late Miocence left lateral strike slip of Aqaba Fault (Fig. 1). Convergent plate margin? began in the Early Oligocene time at the Zagros suture due to the NE movement of African-Arabian Plate. This movement led to crustal stretching and weakening along the proto Red Sea and Gulf of Aden (Hughes and Johnson, 2005), which resulted in the formation of rift basin and deposition of rift sequences that span from Late Oligocene to Recent.

The tectono-stratigraphic evolution of the study area can be summarized in Figure 2. During the Late Oligocene, rifting was well underway and resulted in the deposition of the first syn-rift sediments, the immature fluvio-lacustrine deposit AI-Wajh For- mation. During the tectonic reorganization, small-restricted basins were formed and allowed the deposition of hypersaline basinal evaporites of the Yanbu Formation in the Early Miocene time. Synchronous with this evaporites, the first major carbonate succession was commenced in the study area represented by the Musayr Formation which was deposited in the different part of the half graben. This carbonate succession was deposited under normal saline to brackish water conditions (Hughes and Johnson, 2005). Rapid subsidence was subsequently taken place after the deposition of carbonate unit that led to the increasing accommodation space creation. It allows deposition of deep water turbidites of the Burqan Formation (Al-Ramadan et al., 2013). Tectonic readjustment during late Early Miocene, which was associated with mid-clysmic events on the Gulf of Suez (Bosworth and McClay, 2001) had facilitated the development of palaeohighs bounded by normal faults, allowed the Wadi Waqb carbonates of the Jabal Kibrit Formation to nucleate (Tubbs et al., 2014). The Musayr Formation is stratigra- 


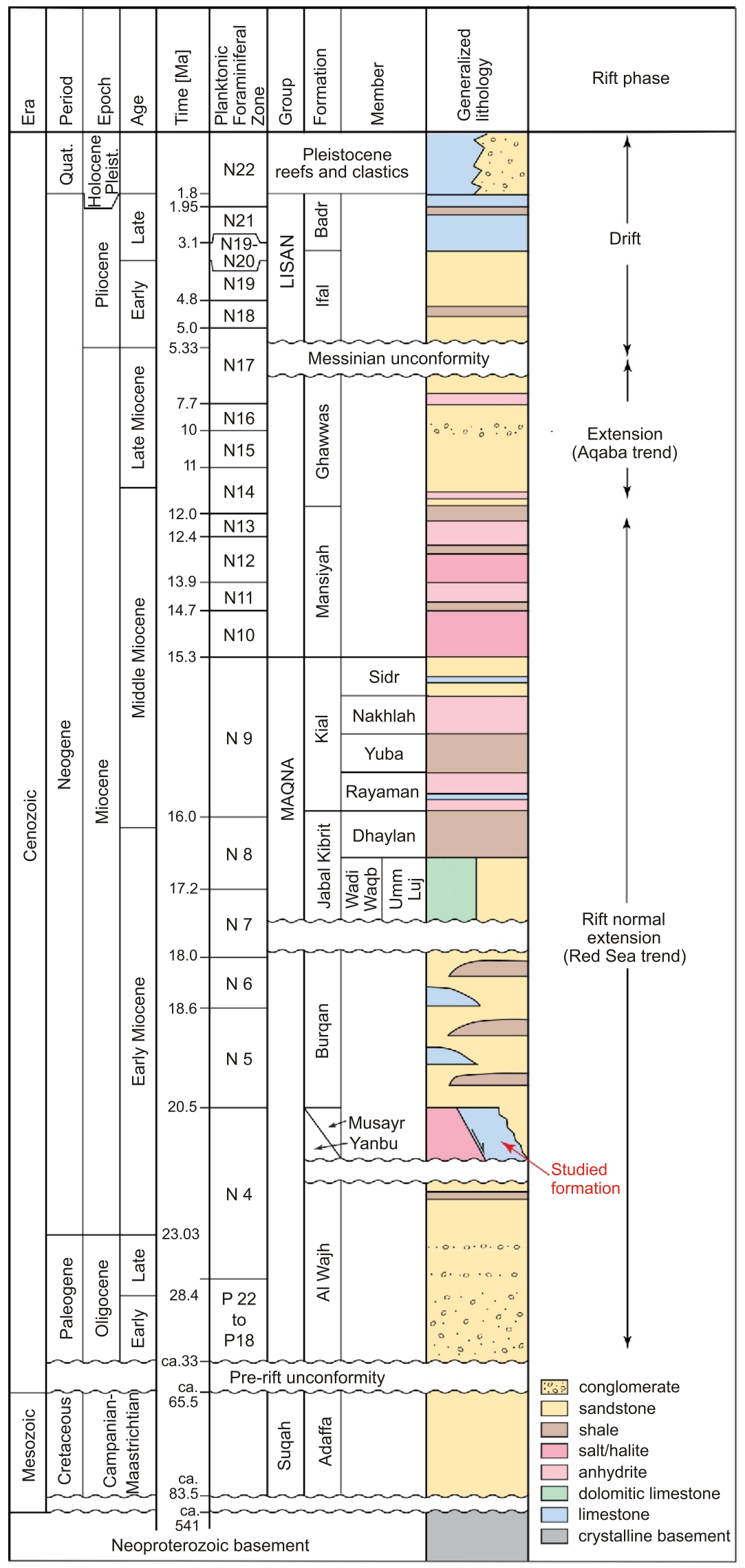

Fig. 2. Lithostratigraphic column of the Red Sea area showing the rift phases and tectonic events from Late Cretaceous to present (modified after Tubbs et al., 2014) 
phically equivalent to the syn rift, Gharamul Member (reefal limestones) of the Nukhul Formation in the Gulf of Suez (Saoudi and Khalil, 1986; Hughes and Johnson, 2005).

\section{METHODOLOGY}

A total of 40 representative carbonate samples from Musayr Formation were collected along two stratigraphic sections in two different locations (Fig. 3). Thin sections prepared for samples impregnated with blue epoxy were studied using standard petrographic technique. The thin sections were stained with Alizarin Red S (Dickson, 1966) to discriminate between calcite and dolomite. Scanning electron microscopy (SEM) and X-ray Diffraction (XRD) were performed to analyse the crystal morphology and bulk mineralogy of the selected samples. Inductively Coupled Plasma Spectrometry (ICP-OES) was conducted on fifteen representative carbonate samples in order to determine the concentration of trace elements ( $\mathrm{Fe}, \mathrm{Mn}, \mathrm{Sr}$ and $\mathrm{Na}$ ). Similar samples were subjected to carbon and oxygen stable isotopes analyses on bulk samples at Stable Isotope Laboratory (SIL), University of Miami. These samples were analysed using a common acid bath interfaced to a Finnigan-MAT 251 mass spectrometer on whole rock of representative carbonate samples. Data are reported using a conventional notation (VPDB) and corrected for the usual interference. The precision for this method is $\pm 0.08 \%$.

\section{RESULTS}

\section{LITHOFACIES}

The Musayr Formation is composed of eleven lithofacies (Table 1), which are distributed throughout the hanging wall dipslope carbonate ramp (Koeshidayatullah et al., 2016). The inner ramp environment is characterized by the presence of basal arkosic sandstones with some pebble lenses, stromatolitic boundstone and bioclastic packstones, which are interbedded with the siliciclastic deposits (Fig. 4A). The ooidal and peloidal grainstones have been deposited in the shoal environment (Fig. 4B). Middle ramp environment is the most dominant environment being mostly composed of oyster rudstone-floatstone, bio-intraclastic packstones and foraminiferal packstone (Fig. 4C-F).

\section{DIAGENESIS}

Various diagenetic processes are recognized and distinguished by the petrographic observations of Musayr carbonate samples from the two studied sections. The petrography study shows that all diagenetic processes, the most important are linked with early diagenetic environments, i.e. diagenetic alterations caused by marine and meteoric waters. This includes a suite of alterations such as dolomitisation, marine cementation, leaching and cementation, which can be observed in the different parts of the Musayr Formation. Of less importance are burial processes that are under the realm of mechanical and chemical compaction, with stylolite and fracture generation.

Micritisation. This process occurs at the earliest stage of marine diagenesis and found at the border of both skeletal and non-skeletal grains (Fig. 5A). The micrite mostly appears in the form of a thin, micrite envelope in the outer rim of grains. Generally, the micrite helps the formation of cement to nucleate and also preserve the grains from subsequent dissolution. This pro- cess is observed in the Musayr Formation especially in the bioclastic wackestone microfacies in low energy lagoon environment.

Cementation. Different types of carbonate cements in the Musayr Formation were distinguished based on their morphology, fabrics and texture. They are divided into two groups of marine and meteoric cements as described below:

1. Marine cements

There are two type of marine cements that can be observed in the studied samples: (1) isopachous fibrous calcite having size up to $100 \mu \mathrm{m}$ in length and usually forms prior to compaction (Fig. 4B). This cement commonly found occupying the pore spaces in grainstones and grain-dominated packstone. Although in each case primary textures can be well-preserved, they have undoubtedly undergone various degrees of recrystallisation (e.g., from metastable to stable mineralogies) and geochemical alteration; (2) mosaic calcite cement characterized with a polycristalline nature with xenomorphic pattern. This type of cement has size up to $200 \mu \mathrm{m}$ in width and is mostly associated with fractures and also fill the intra- and intergranular pore spaces. The presence of mosaic cement has significantly caused porosity reduction (Fig. 4F).

2. Meteoric cements

Meteroic cements are found in many samples with three different forms: (1) drusy calcite cement having coarse crystal (size up to $400 \mu \mathrm{m}$ in width) and progressively becomes coarser towards the centre of the pore (Fig. 5B); and (2) blocky cement with various crystal size ranging from 200 to $400 \mu \mathrm{m}$ and has xenotopic crystal fabric. This cement occurs mostly as pore filling (Fig. 5C); (3) meniscus cement having fine crystal size and is mostly recognized near grain to grain contacts (Fig. 5D).

Dissolution. The dissolution process took place in two different stages: (1) early stage of micrite and skeletal grains dissolution that resulted in formation of intragranular and moldic porosity (Fig. 5E). This stage predates the mechanical compaction where dissolved shells are readily and preferentially compacted; (2) late stage dissolution of blocky-mosaic calcite and dolomite cements with porosity enhancement (Fig. 4F).

Compaction. Mechanical and chemical compactions were observed in the study samples. Mechanical compaction is represented by reorganization, deformation, and fracturing of bioclastic grains such as coralline-algal fragments and brachiopod/bivalve shells (Fig. 5F). Chemical compaction is exemplified by microstylolites (grain-to-grain sutured contacts; Fig. 5D), and, locally, by more persistent stylolites and cross-cutting grains (Fig. 5G).

Dolomitisation. Dolomite can be observed in outcrop scale as a dark brown colour. In thin section, it occurs as a coarse crystal that has mostly filling features (Figs. $3 \mathrm{~A}$ and $5 \mathrm{H}$ ).

\section{STABLE ISOTOPE AND TRACE ELEMENTS}

The stable isotope values of the Musayr carbonate sequences in both localities are presented in Table 2 . The $\delta^{18} \mathrm{O}$ values range between -10.08 and $-6.91 \%$ (avg. $-9.08 \%$,), and $\delta^{13} \mathrm{C}$ values range between -4.72 and $3.09 \%$ (avg. $-1.60 \%$; Table 2).

Strontium. The $\mathrm{Sr}$ concentration in the Musayr carbonate ranges from 29.5 to 2032 ppm (avg. 347 ppm). Maqna location shows relatively higher strontium concentration in comparison with Wadi Al-Hamd area.

Sodium. The $\mathrm{Na}$ concentration in the Musayr carbonate ranges from 277 to 4474 ppm (avg. 1180 ppm). Higher sodium concentration is observed in the lower part of Musayr Formation succession in Maqna area. 

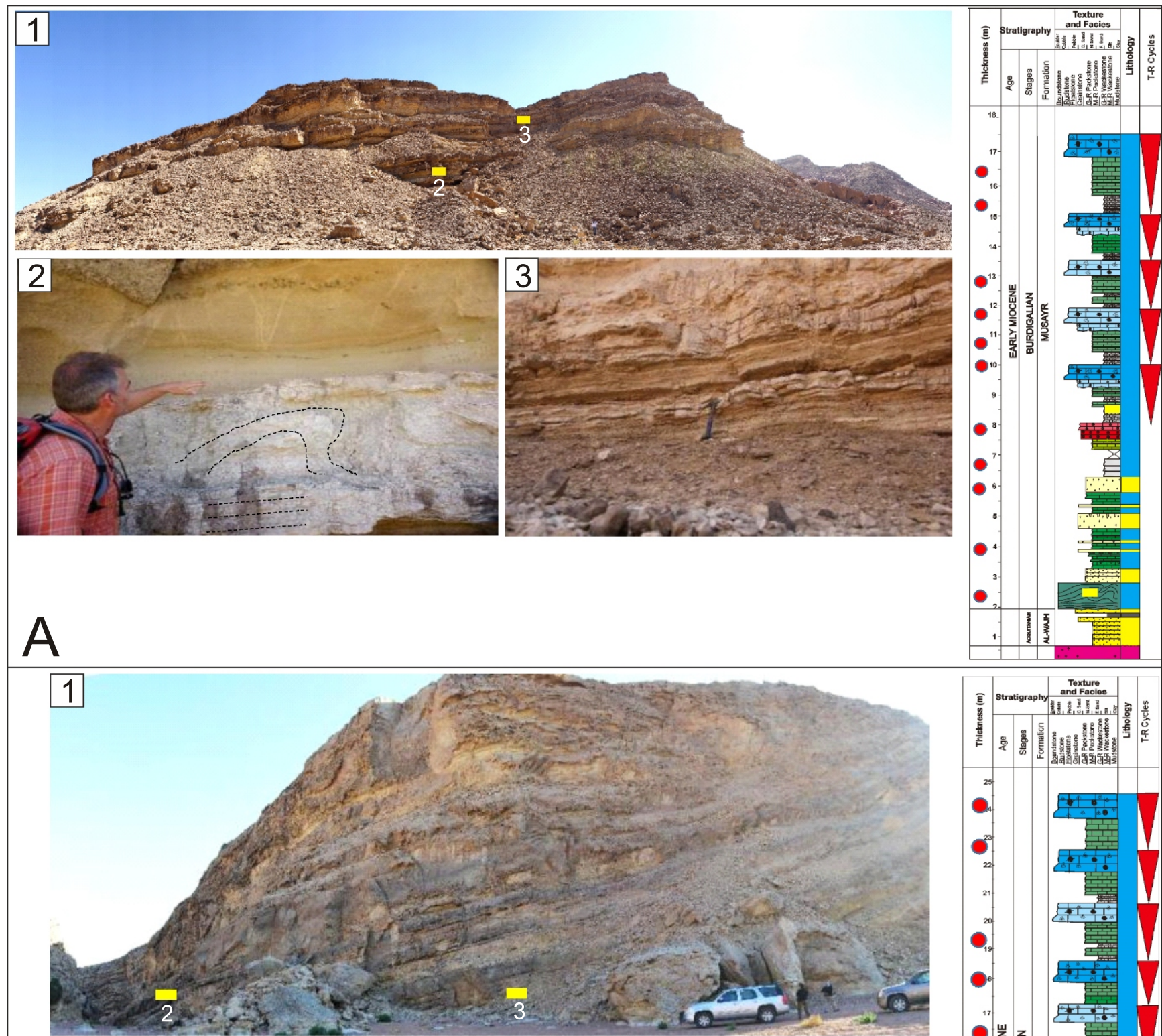

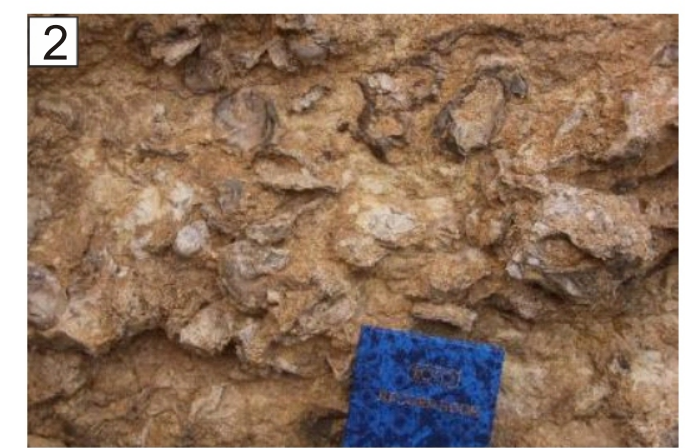

$\square$ foraminiferal packstone
$\square$ calcareous sandstone
$\square$ stromatolitic boundstone
$\square$ bioclastic wacke-packstone

ooidal grainstone peloidal grainstone

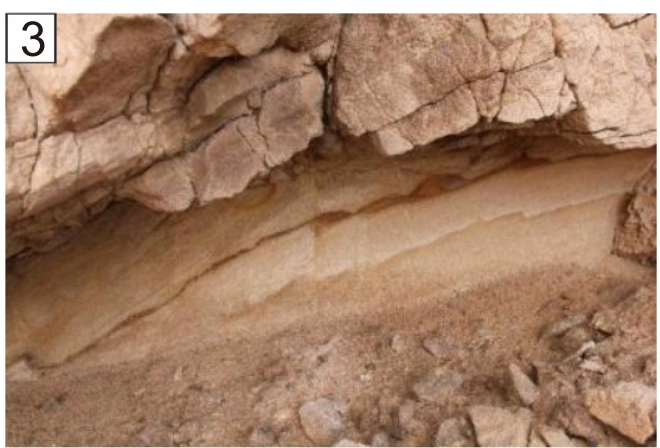
bio-intraclastic packstone oyster-rich rudstone

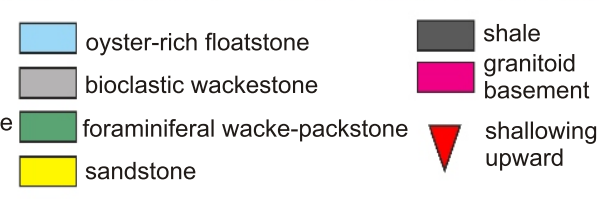

Fig. 3. Measured stratigraphic sections from two different localities:

A - in Maqna (circle no. 1 in Figure 1): 1 - panoramic view of the studied section, 2 - the light grey stromatolite facies intruded by dark brown fractures filled dolomite, 3 - interbedded bioclastic wacke- to pack-stone layers; $\mathbf{B}$ - in Wadi Al-Hamd (circle no. 2 in Figure 1): 1 - panoramic view of the studied section, 2 - oyster-rich beds that are commonly found in the upper section of Musayr Formation, 3 - the presence of minor faults that represent post-depositional tectonic events affecting the Musayr carbonate sequence 
Summary of Musayr carbonates

\begin{tabular}{|c|c|c|c|c|c|}
\hline $\begin{array}{l}\text { Lithofacies } \\
\text { code }\end{array}$ & Lithofacies & $\begin{array}{l}\text { Facies as- } \\
\text { sociation }\end{array}$ & Description & Porosity type & $\begin{array}{l}\text { Hydrodynamic } \\
\text { energy }\end{array}$ \\
\hline F1 & $\begin{array}{l}\text { Foraminiferal } \\
\text { packstone }\end{array}$ & FA1 & $\begin{array}{l}\text { Typically found interbedded with calcareous sand- } \\
\text { stone. Composed mostly of miliolids foraminifera } \\
\text { (Quinqueloculina spp) and other skeletal frag- } \\
\text { ments, such as bivalves and gastropods. }\end{array}$ & $\begin{array}{l}\text { Intergranular, } \\
\text { intragranular }\end{array}$ & Low \\
\hline $\mathrm{F} 2$ & $\begin{array}{l}\text { Calcareous } \\
\text { sandstone }\end{array}$ & FA1 & $\begin{array}{l}\text { Composed of mostly quartz and plagioclase } \\
\text { grains. The grains are subangular to subrounded. } \\
\text { Lenses of pebbles are commonly associated with } \\
\text { this facies. Burrows are common. Cross-stratifica- } \\
\text { tion found in some cases. }\end{array}$ & $\begin{array}{l}\text { Intergranular, } \\
\text { fracture }\end{array}$ & Moderate to high \\
\hline F3 & $\begin{array}{c}\text { Bioclastic } \\
\text { wacke-packstone }\end{array}$ & FA1 & $\begin{array}{l}\text { Normally graded and well stratified. Composed of } \\
\text { a mixture of skeletal fragments, such as rhodoliths, } \\
\text { miloilids foraminifera, gastropods, and bivalves. }\end{array}$ & $\begin{array}{l}\text { Intergranular, } \\
\text { fracture }\end{array}$ & Low to moderate \\
\hline $\mathrm{F} 4$ & $\begin{array}{l}\text { Stromatolitic } \\
\text { boundstone }\end{array}$ & FA1 & $\begin{array}{c}\text { Common fenestral fabric. Most of the grains are } \\
\text { recrystallised. }\end{array}$ & Fenestral & Low to moderate \\
\hline F5 & Ooidal grainstone & FA2 & $\begin{array}{l}\text { Well stratified and extensive lateral continuity. Well } \\
\text { sorted ooid grains with concentric cortex arrange- } \\
\text { ments. The nuclei are mostly composed of quartz } \\
\text { fragments. }\end{array}$ & $\begin{array}{l}\text { Intergranular, } \\
\text { intragranular }\end{array}$ & High \\
\hline F6 & Peloidal grainstone & FA2 & $\begin{array}{l}\text { Typically found associated with ooidal grainstone. } \\
\text { Massive and with lime mud pellets, micritic } \\
\text { intraclasts, variable amounts of silt-sized quartz, } \\
\text { minor bioclasts (gastropods, brachiopods). }\end{array}$ & $\begin{array}{l}\text { Intercrystalline } \\
\text { porosity }\end{array}$ & Moderate \\
\hline F7 & $\begin{array}{l}\text { Bioclastic- } \\
\text { packstone }\end{array}$ & FA3 & $\begin{array}{l}\text { Normal grading, mostly composed of various } \\
\text { bioclast fragments (benthic foraminifera, } \\
\text { rhodoliths) and intraclasts. Intensive bioturbation. }\end{array}$ & Intergranular & Moderate to high \\
\hline F8 & Oyster floatstone & FA3 & $\begin{array}{l}\text { Typically found associated with the rudstone and } \\
\text { bioclast-intraclast packstone facies. Floating oys- } \\
\text { ter fragments within packstone matrix. }\end{array}$ & $\begin{array}{l}\text { Intergranular, } \\
\text { vuggy }\end{array}$ & High \\
\hline F9 & Oyster rudstone & FA3 & $\begin{array}{l}\text { Typically found associated with the floatstone fa- } \\
\text { cies (F8). Oyster fragments more dominant, matrix } \\
<10 \% \text {. Planar to low-angle cross stratification. }\end{array}$ & $\begin{array}{l}\text { Intergranular, } \\
\text { vuggy }\end{array}$ & High \\
\hline F10 & $\begin{array}{l}\text { Foraminiferal } \\
\text { packstone }\end{array}$ & FA3 & $\begin{array}{c}\text { This facies mostly comprise ramp-derived frag- } \\
\text { ments. Abundant benthic forams (Miogypsina sp) } \\
\text { and minor bioclasts (bivalves, gastropods) charac- } \\
\text { terize this facies. }\end{array}$ & Intergranular & Moderate to high \\
\hline F11 & $\begin{array}{l}\text { Bioclastic } \\
\text { wackestone }\end{array}$ & FA3 & $\begin{array}{c}\text { Diverse fossil content and abundant micrite. Asso- } \\
\text { ciated with the oyster rudstone and found com- } \\
\text { monly at the base of cycles. Bioturbation is } \\
\text { observed in this facies. }\end{array}$ & Intergranular & Low \\
\hline
\end{tabular}

Iron and manganese. The $\mathrm{Fe}$ and $\mathrm{Mn}$ concentrations in the Musayr carbonates range from 302 to 3560 ppm (avg. 1388 ppm) and from 422 to 2489 ppm (avg. 1444 ppm), respectively.

\section{DISCUSSION}

\section{PARAGENETIC SEQUENCE}

Based on the petrographic characteristics and their elemental compositions, the timing of diagenetic events and their environmental evolution of the Musayr Formation can be inferred. Three different diagenetic environments (marine, meteoric and burial) are recognized and discussed below (Fig. 6).

Marine diagenesis. Marine diagenesis is represented by the presence of micrite envelope, microbial micritisation and isopachous rim. The micrite envelope and isopachous rim are mostly associated with high-energy grain-dominated facies whereas the micritisation is more abundant in the low energy mud-dominated facies. The long and point contacts nature of the grains and the pre-compaction nature of the cement may suggest concurrent occurrence of marine cementation and early compaction (Jadoul and Galli, 2008; Ronchi et al., 2011). Trace elemental cross plots indicate aragonite-high magne- sium calcite as the original mineralogy before it undergone severe meteoric diagenesis (Fig. 7).

Burial diagenesis. This stage is characterized by chemical compaction and intensive dissolution (Fig. 5F, G). These features are recognized under thin section by suture grain contacts, grain interpenetration and creation of moldic pores. Additionally, coarse crystalline with undulatory extinction of dolomite mineral may also suggest late burial, high-tempreture fluids origin. The position of Musayr platform that was located on the palaeohighs of Midyan Basin may explain little influence of burial diagenesis.

Meteoric diagenesis. This diagenetic realm is the most dominant in the Musayr Formation in both localities and characterized by clear blocky (Fig. 5C) and drusy mosaic cements, followed by selective dissolution by using fractures as the pathways. Most of the meteoric cements formed as low magnesium calcite (LMC) and progressively occluded primary pore spaces in the grain-dominated carbonate facies and filled the fractures. The average value of strontium concentration (347 ppm) in the LMC may be attributed to the dissolution of the unstable marine carbonates (aragonite and $\mathrm{HMC}$ ) that releases strontium to the pore waters.

Meteoric diagenesis occurs during eodiagenesis via meteoric water flux enhanced by subaerial exposure of carbonate sequence (e.g., Fheed et al., 2015). The presence of meniscus cement at the grain contacts has been interpreted to occur in 

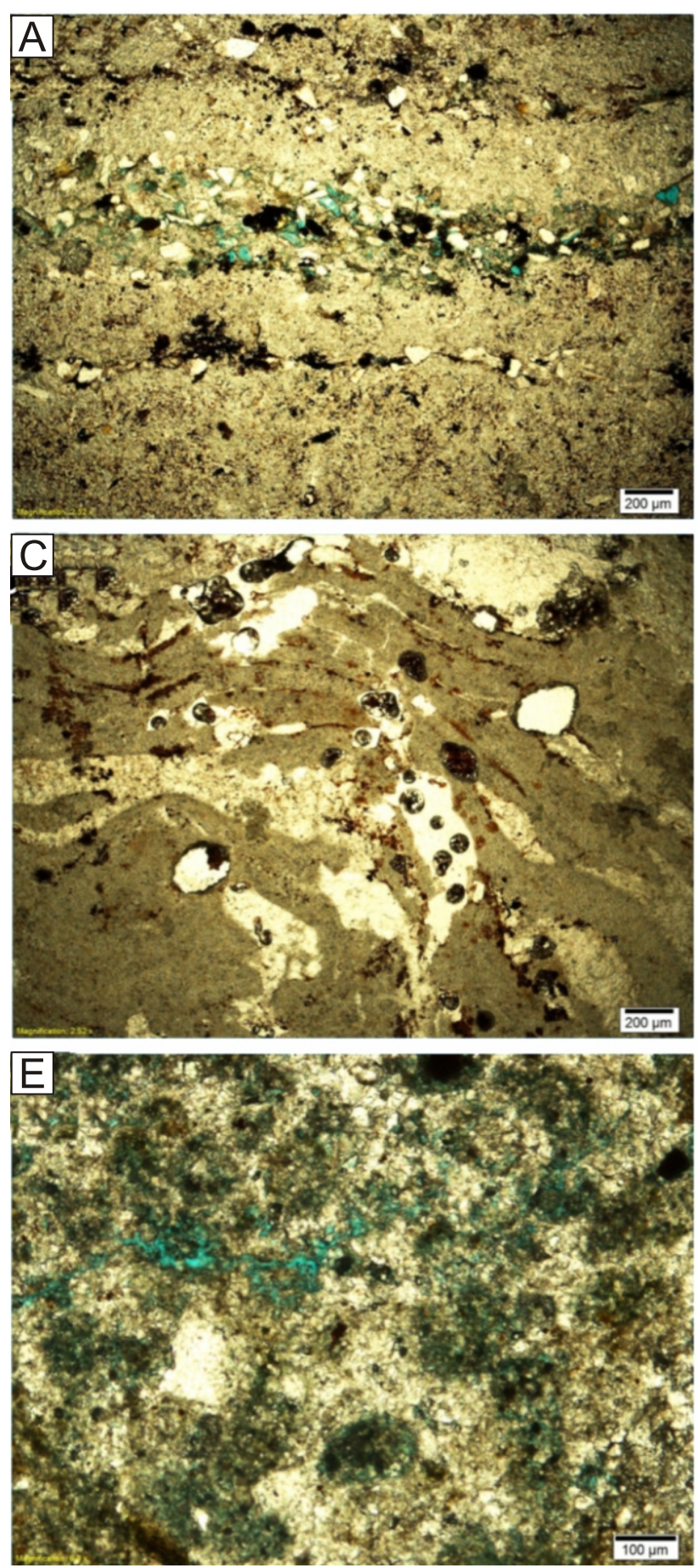
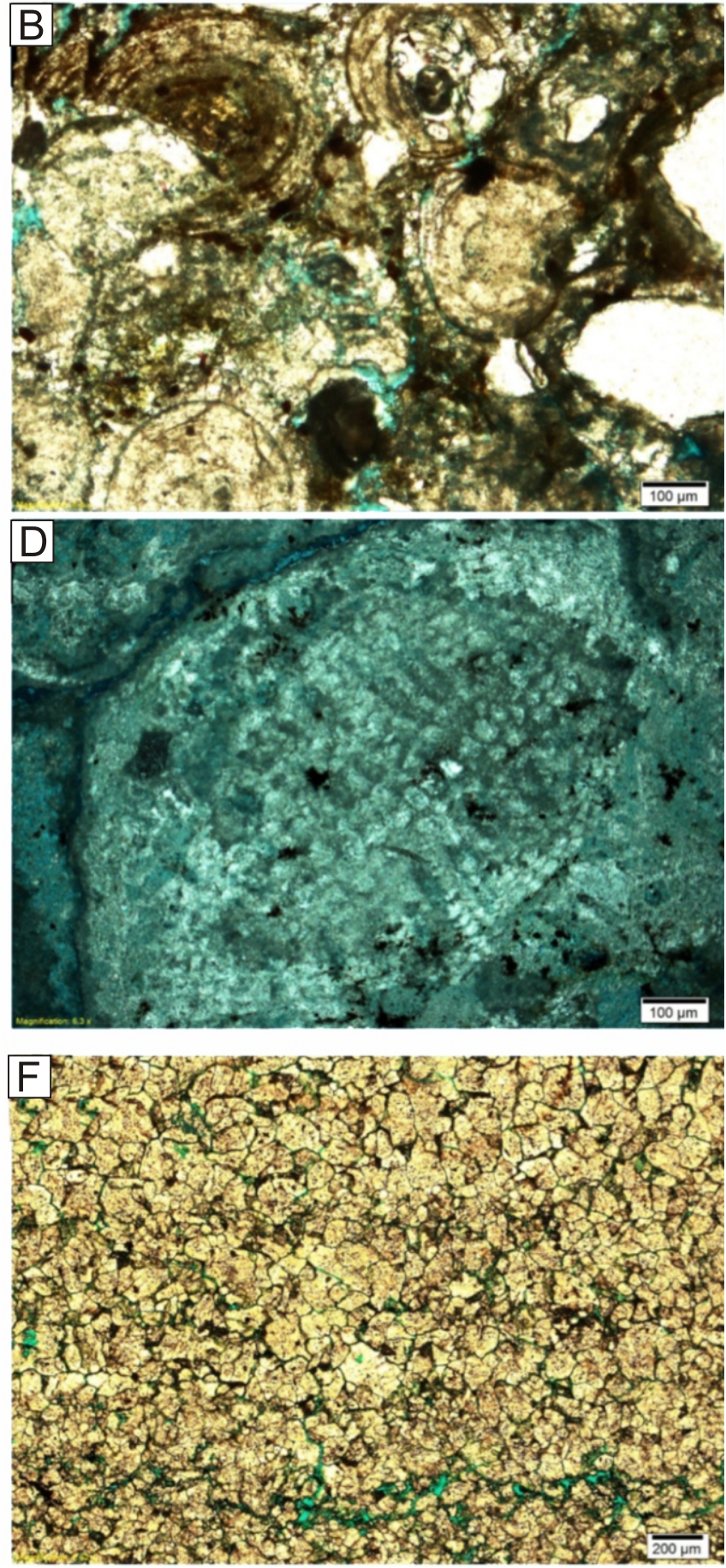

Fig. 4. Thin section micrograph of the Musayr Formation display different microfacies

A - stromatolitic boundstone with siliciclastic grains entrapped within the laminae, equant and coarse calcite crystals are evident from the thin section; B - ooid grains with tangential cortices, grain interpenetration can be observed as an evidence of deep burial compaction; C rhodolith encrustation; D - calcite replacement of benthic foraminifera (Miogypsina sp.); $\mathbf{E}$ - partial dissolution on peloidal and bioclastic grains and coarse, blocky cement filling the pore space; $\mathbf{F}$ - equant and coarse calcite cements that profound in the Musayr Formation 

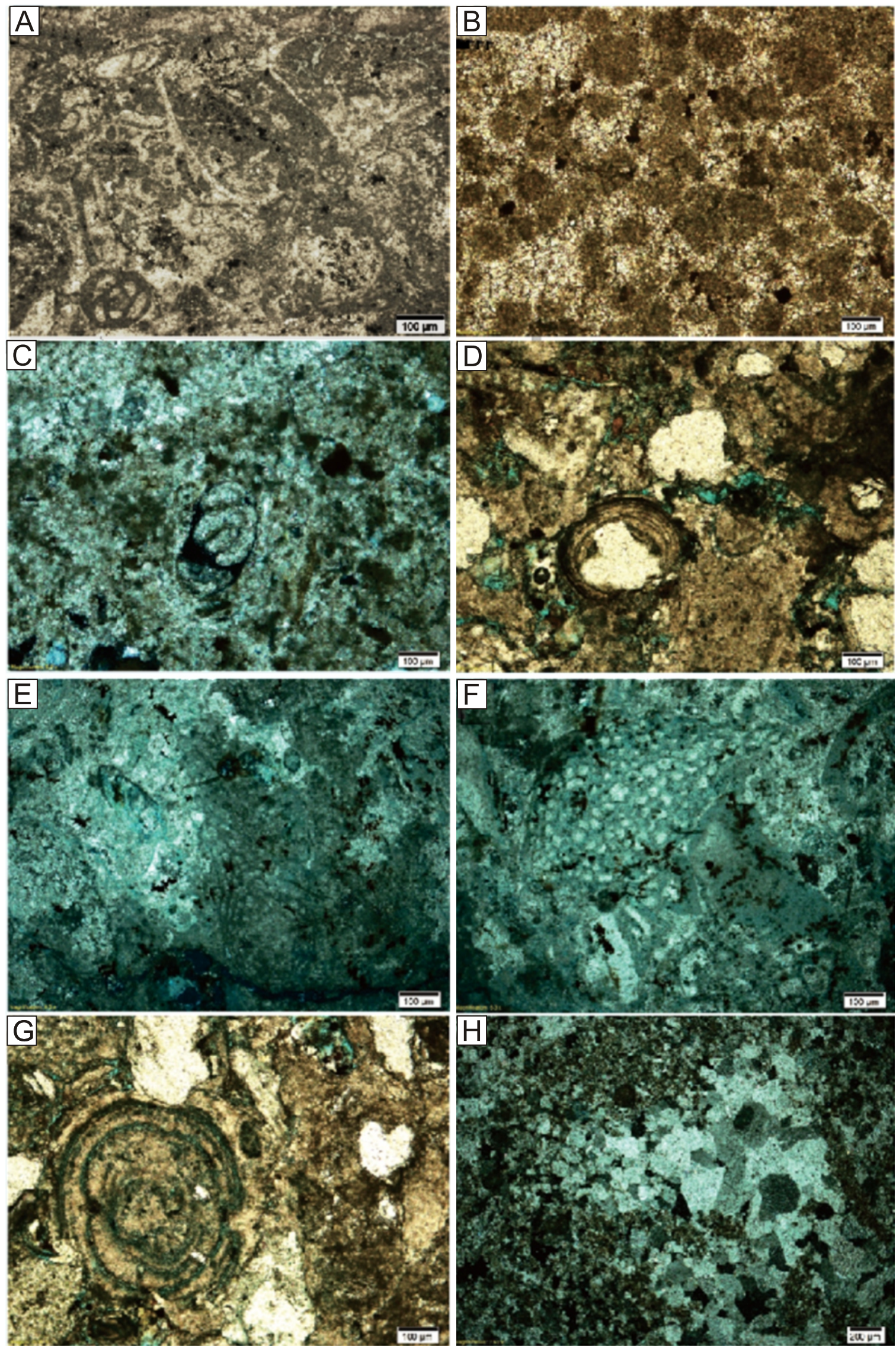

Fig. 5. Thin section images of the Musayr Formation show various diagenetic features

A - intensive microbial micrttisation on the skeletal grains; B - drusy cement in the peloidal grainstone facies; C - blocky cement observed as replacing and pore-filling material; $\mathbf{D}$ - meniscus cement within grains, an indicator of meteoric vadose environment; $\mathbf{E}$ - intergranular and moldic porosity as a product of intensive dissolution, second stage of dissolution that dissolved late dolomite cement; $\mathbf{F}$ - long and point contacts between grain suggesting mechanical compaction; $\mathbf{G}$ - grain interpenetration suggesting intensive burial compaction; $\mathbf{H}$ - late dolomite cement that filling the fractures 
Percentage of calcite and dolomite obtained from XRD and the carbon and oxygen isotopes of the Musayr Formation

\begin{tabular}{|c|c|c|c|c|c|c|c|c|c|c|c|}
\hline $\begin{array}{c}\text { Loca- } \\
\text { tion }\end{array}$ & $\underset{\text { ID }}{\text { Sample }}$ & $\begin{array}{l}\mathrm{Ca} \\
{[\%]}\end{array}$ & $\begin{array}{l}\mathrm{Mg} \\
{[\%]}\end{array}$ & $\begin{array}{c}\mathrm{Fe} \\
{[\mathrm{ppm}]}\end{array}$ & $\begin{array}{c}\mathrm{Mn} \\
{[\mathrm{ppm}]}\end{array}$ & $\begin{array}{c}\mathrm{Na} \\
{[\mathrm{ppm}]}\end{array}$ & $\begin{array}{c}\mathrm{Sr} \\
{[\mathrm{ppm}]}\end{array}$ & $\begin{array}{l}\delta^{13} \mathrm{C} \\
{[\% 0]}\end{array}$ & $\begin{array}{l}\delta^{18} \mathrm{O} \\
{[\% 0]}\end{array}$ & $\begin{array}{c}\text { Dolomite } \\
{[\%]}\end{array}$ & $\begin{array}{c}\text { Calcite } \\
{[\%]}\end{array}$ \\
\hline \multirow{7}{*}{$\begin{array}{l}\text { Wadi } \\
\text { Alhamd }\end{array}$} & $\mathrm{WH}-4$ & 10.98 & 0.11 & 732.6 & 891.3 & 700.6 & 42.1 & -2.68 & -9.41 & 0 & 100 \\
\hline & WH-5 & 31.75 & 0.13 & 1033.6 & 1949.1 & 365.0 & 110.6 & -2.71 & -9.74 & 0 & 100 \\
\hline & WH-6 & 10.09 & 0.08 & 302.3 & 664.3 & 580.9 & 31.5 & -2.74 & -10.08 & 0 & 100 \\
\hline & WH-7 & 27.55 & 0.28 & 2008.5 & 1578.3 & 753.0 & 112.9 & -2.57 & -9.11 & 0 & 100 \\
\hline & WH-8 & 11.55 & 0.18 & 1394.3 & 422.8 & 1097.2 & 29.5 & -0.45 & -7.58 & 0 & 100 \\
\hline & WH-9 & 28.09 & 0.12 & 392.3 & 1167.7 & 571.4 & 136.0 & -0.74 & -9.09 & 0 & 100 \\
\hline & WH-10 & 42.71 & 0.16 & 306.2 & 1215.6 & 393.4 & 152.7 & -0.47 & -9.81 & 0 & 100 \\
\hline \multirow{8}{*}{ Maqna } & M-3 & 42.04 & 0.26 & 990.4 & 1939.6 & 277.1 & 280.4 & -0.56 & -6.91 & 0 & 100 \\
\hline & $\mathrm{M}-4$ & 24.43 & 0.30 & 1629.9 & 2489.8 & 4474.3 & 134.2 & -4.72 & -9.93 & 0 & 100 \\
\hline & $M-5$ & 21.02 & 0.51 & 3556.5 & 1506.8 & 3397.5 & 136.3 & -4.72 & -9.14 & 0 & 100 \\
\hline & M-6 & 15.71 & 0.56 & 3560.3 & 1776.8 & 2919.5 & 170.5 & -2.89 & -9.39 & 0 & 100 \\
\hline & M-7 & 35.56 & 0.34 & 1404.5 & 2429.4 & 980.0 & 201.5 & -2.59 & -9.72 & 0 & 100 \\
\hline & M-8 & 37.35 & 0.36 & 1366.4 & 1962.5 & 470.5 & 294.5 & -0.98 & -8.47 & 0 & 100 \\
\hline & M-9 & 32.80 & 0.29 & 1684.5 & 873.6 & 367.9 & 1347.8 & 1.77 & -9.42 & 0 & 100 \\
\hline & $M-10$ & 44.06 & 0.23 & 453.0 & 796.9 & 356.5 & 2032.0 & 3.09 & -8.41 & 0 & 100 \\
\hline
\end{tabular}

meteoric vadose environment (Tucker and Wright, 1990). This may be explained by the footwall uplift during rift phase prior to post-rift subsidence phase. This has been reported in Gulf of Suez, where local but important phase of subaerial exposure allows lateral influx of meteoric waters into the Miocene carbonate of Abu Shaar Platform (Aissaoui et al., 1986). Our studied carbonate sequence has been preceded by post Miocene clastics and this suggests peripheral uplift and influx of meteoric water that resulted in dolomitisation of the pre-exiting Miocene carbonate sequence.

\section{ORIGIN OF METEORIC FLUID}

The petrography and geochemical data were used to decipher the presence of meteoric diagenesis realm in the studied carbonate sequence. Cross-plots between various parameters (trace el- ements and stable isotopes) and relationships have been utilized to explain the formation of Musayr carbonate sequences.

\section{GEOCHEMICAL SIGNATURES OF METEORIC DIAGENESIS}

Previous studies have demonstrated that shallow marine carbonates $\delta^{13} \mathrm{C}$ values are not readily affected by diagenetic alterations (Banner and Hanson, 1990). Conversely, $\delta^{18} \mathrm{O}$ values of marine carbonate rocks are easily influenced by burial and meteoric diagenesis (Brand and Veizer, 1981; Brand, 2004). The integration of carbon and oxygen isotopes with trace elemental analysis have unraveled specific trends that may suggest the presence of meteoric diagenesis in the studied carbonate platform (Figs. 7 and 8).

Carbon isotope values of the Musayr Formation in the Maqna location (Fig. 7) exhibit a marked depletion relative to

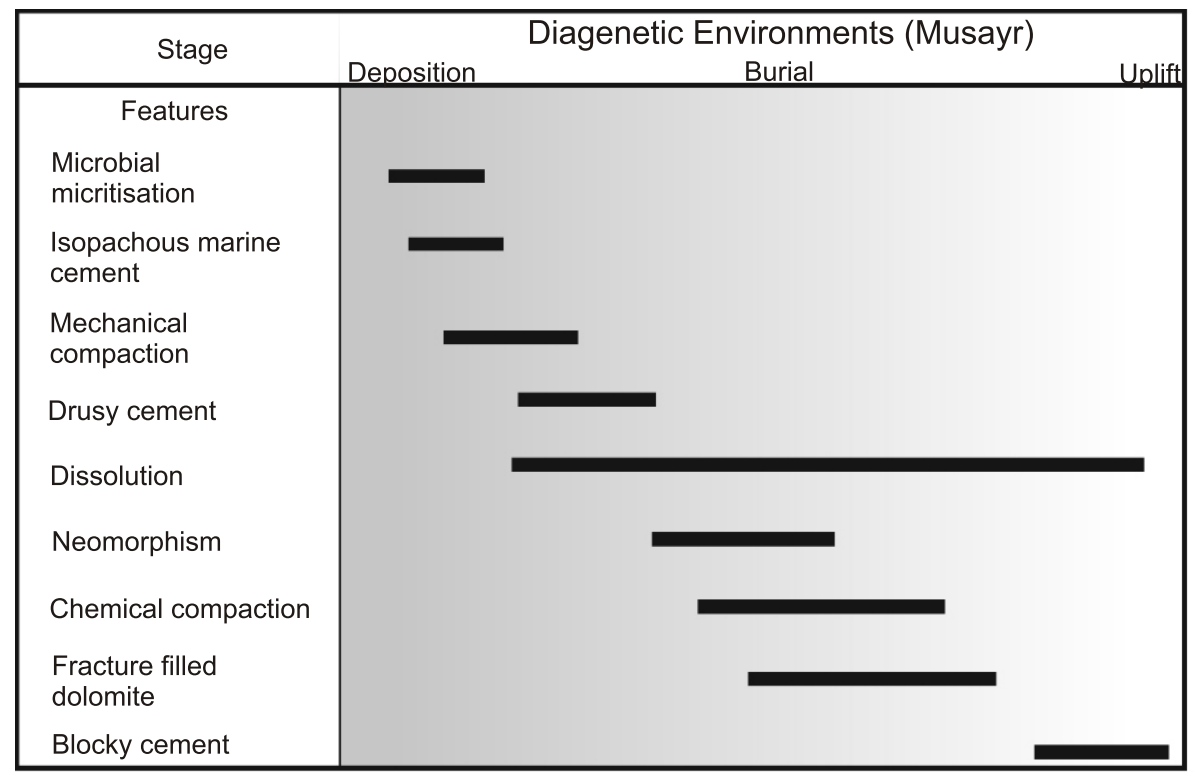

Fig. 6. Paragenetic sequence of Musayr Formation shows a dominant meteoric diagenesis 

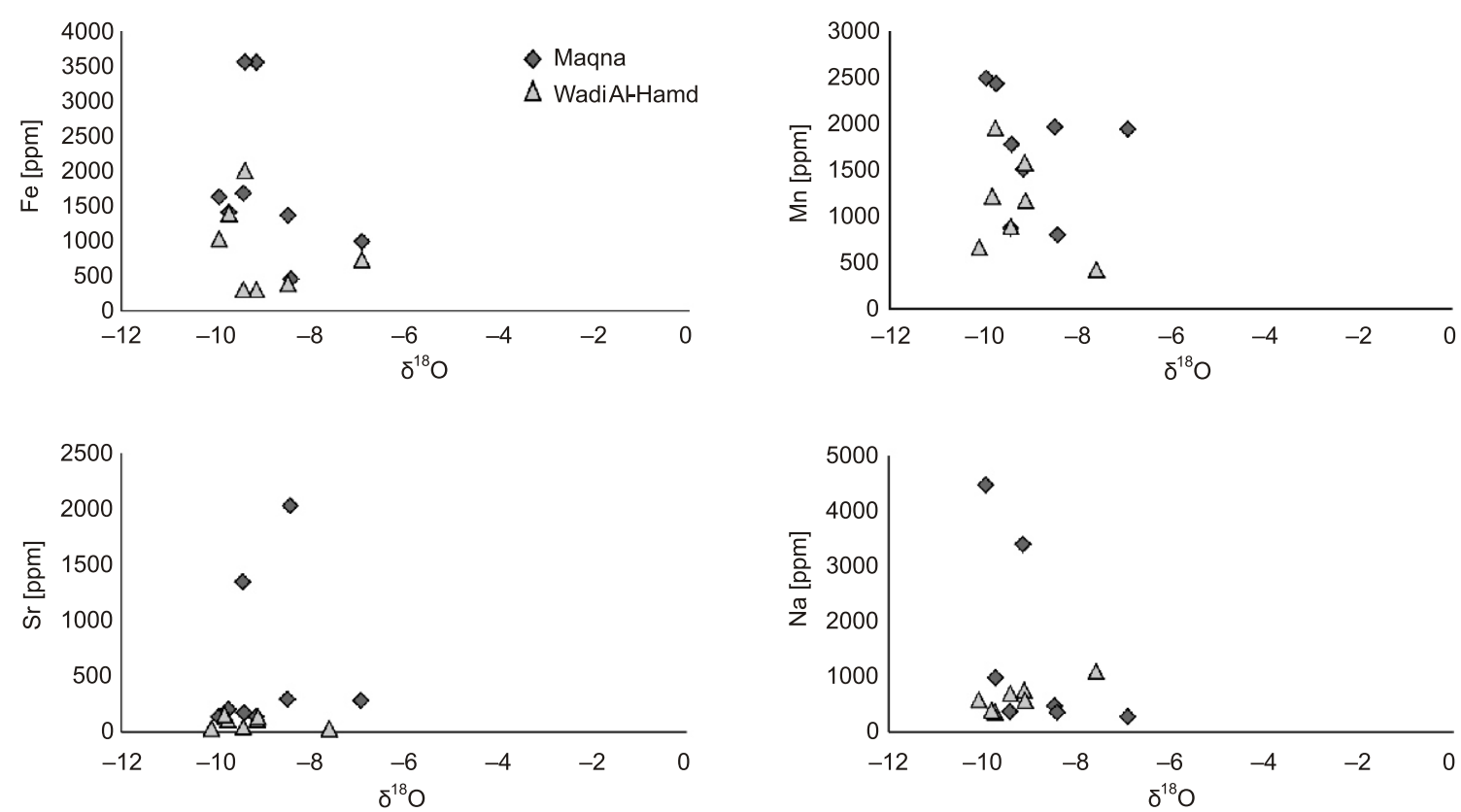

Fig. 7. Cross-plot between $\delta^{18} \mathrm{O}$ and different trace elements ( $\left.\mathrm{Fe}, \mathrm{Mn}, \mathrm{Sr}, \mathrm{Na}\right)$ of the carbonate sequence of Musayr Formation in the two studied areas

Note that $\delta^{18} \mathrm{O}$ depleted calcites have high Na concentrations
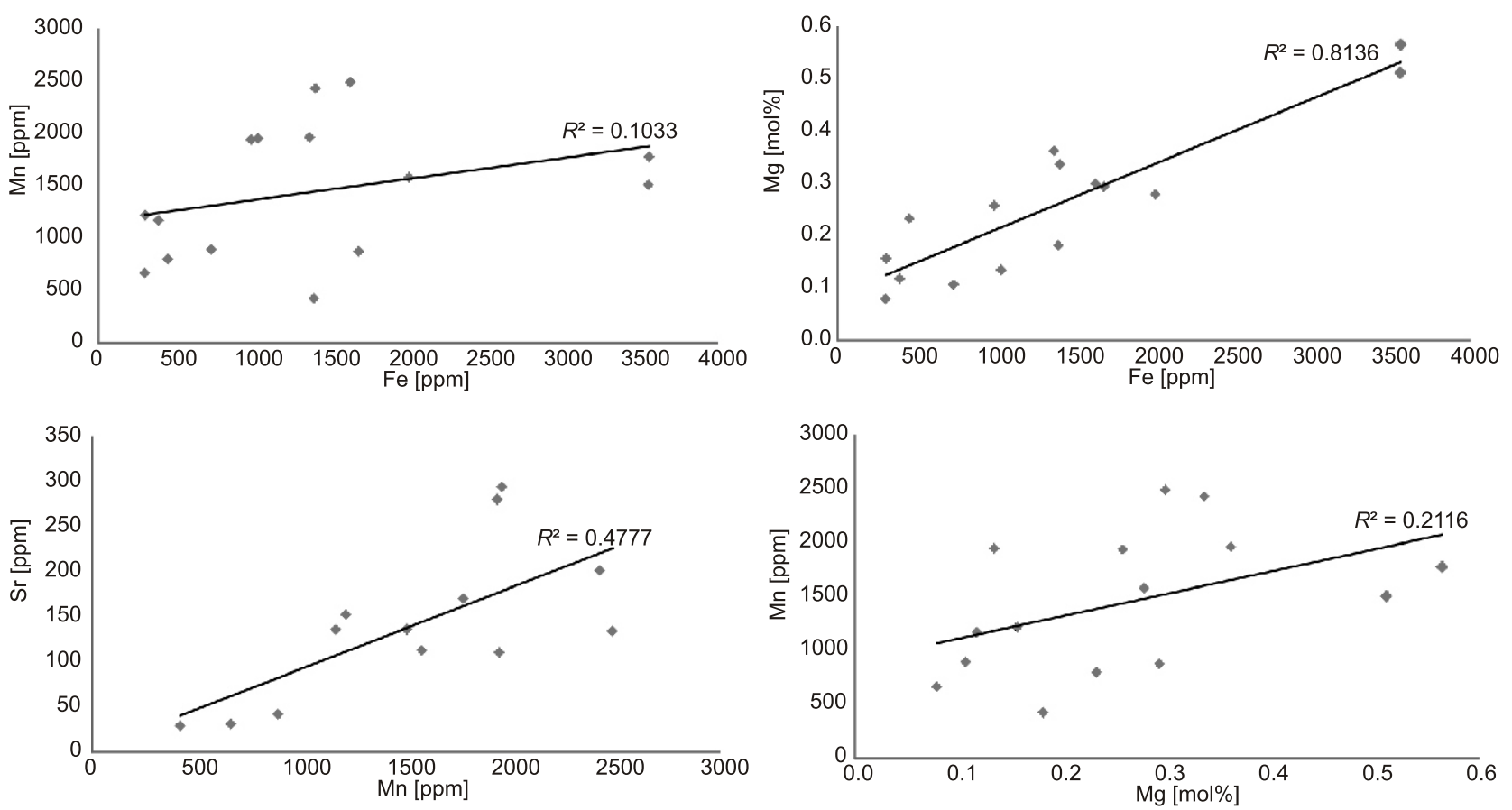

Fig. 8. Cross-plot between various trace elements

$\mathrm{Fe}, \mathrm{Mn}$, and Sr have been utilized because their sensitivity to diagenetic fluid changes, especially meteoric diagenesis. Three of four different cross-plots exhibit positive correlation that can be used to indicate pervasive meteoric alteration to the Musayr carbonate sequences 


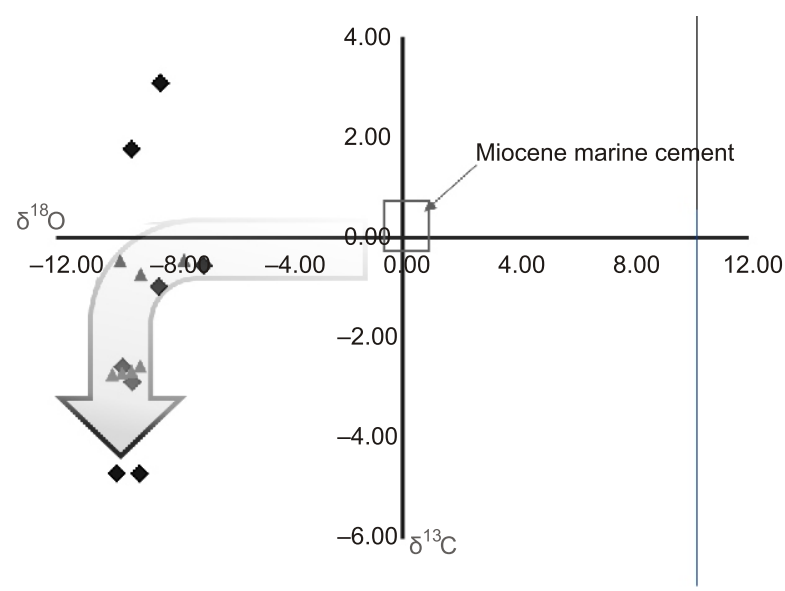

Fig. 9. Cross-plot between $\delta^{18} \mathrm{O}$ and $\delta^{13} \mathrm{C}$ showing inverted J-curve that may suggest meteoric diagenesis

Explanations as in Figure 7

marine carbon signatures at exposure surfaces and become more enriched with depth. Such trends represent an initial input of ${ }^{13} \mathrm{C}$-poor bicarbonate from soil organic processes and progressive addition of ${ }^{13} \mathrm{C}$-rich bicarbonate from interaction with the carbonate host rock (e.g., Allan and Matthews, 1982).

Cross-plots between trace elements ( $\mathrm{Fe}, \mathrm{Mn}, \mathrm{Sr}$ and $\mathrm{Na}$ ) and $\delta^{18} \mathrm{O}$ values (Fig. 7) have shown general trends that also support the interpretation of pervasive meteoric diagenesis in the Musayr Formation, such as negative correlation between $\delta^{18} \mathrm{O}$ and manganese $(\mathrm{Mn})$. This negative correlation may suggest higher incorporation of $\mathrm{Mn}$ elements derived by freshwater into the carbonate sequence (Whitaker et al., 2006).

Different cross-plots confirmed the severe effect of meteoric diagenesis such as the increasing iron and manganese concentrations and positive correlation between them (Fig. 8) These elements can be easily incorporated into calcite structure where the reduction condition is prolonged. Positive correlations between manganase and strontium as well as manganese and iron (Fig. 8) suggest meteoric diagenesis on the Musayr Formation (Winefield et al., 1996).

It is understood that high manganese concentration in calcite is attributed to meteoric diagenesis because of the high manganese content in the meteoric waters (Brand and Veizer, 1980; Rao, 1991). Beside, the increasing concentration of manganese may also be used to infer partially open system and reduction diagenetic realm conditions. Another supporting evidence of meteoric diagenesis is low strontium concentration because its low content on the meteoric waters (Winefield et al., 1996).

The inverted J-curve delineated by Musayr samples is indicative of diagenetic alteration governed by variable degrees of fluid-rock interaction and meteoric origin of diagenetic fluids (e.g., Meyers and Lohmann, 1985; Lohmann, 1988; Banner and Hanson, 1990). This inverted trend may be associated with different isotopic equilibration between carbonate components and diagenetic fluids at low fluid rock interactions (Bishop et al., 2014; Fig. 9). There is no distinct trend or relationship between Dunham's texture and depletion of isotopic components. This may suggest that the trend is governed by microscale structure such as microporosity that cannot be captured by Dunham texture classification (Batt et al., 2008; Bishop et al., 2014).

\section{CONCLUSIONS}

The petrographic, stable isotope and trace element results indicate that:

1. Pervasive meteoric diagenesis is evident feature in the Musayr carbonate sequence and it is mainly characterized by the presence of coarse and equant calcite cements.

2. Depletion of stable isotopes values of both oxygen (avg. $-9.08 \%$ ) and carbon (avg. $-1.6 \%$ ) and trace elements (avg. values of Fe: 1387 ppm; Mn: 1444 ppm; Sr: $419 \mathrm{ppm}$; Na: $1194 \mathrm{ppm}$ ) in conjunction with negative correlation between $\mathrm{Mn}^{2+}$ and oxygen isotope data suggest that these calcite cements were precipitated from fluids of meteoric origin.

3. The meteoric diagenesis have been interpreted to be as a product of early diagenesis (eodiagenesis) that is associated with the interplay between active freshwater input from the hinterland (NE) that brought siliciclastic sediments and several episodes of relative sea level lowstands during the time of deposition in the Early Miocene.

4. Understanding the timing of meteoric diagenesis and its related diagenetic products is important because it may provide information on the presence and extent of these features in the subsurface and hence the influence on reservoir quality distribution throughout this study area and other syn-rift carbonate sequences in other parts of the world.

Acknowledgements. The author would like to acknowledge the support provided by King Abdul Aziz City for Science and Technology (KACST) through the National Science and the Technology Initiative Program at King Fahd University of Petroleum and Minerals (KFUPM) for funding this project (NSTIP \# 11-OIL2145-04). I acknowledge also constructive reviews from the Geological Quarterly referees, R. Aubrecht and anonymous one, and T.M. Peryt that improved this paper.

\section{REFERENCES}

Aissaoui, D.M., Coniglio, M., James, N.P., Purser, B.H., 1986 Diagenesis of a Miocene reef-platform: Jebel Abu Shaar, Gulf of Suez, Egypt. In: Reef Diagenesis (eds. J.H. Schroeder and B.H. Purser): 112-31, Springer, Berlin.

Allan, J.R., Matthews, R.K., 1977. Carbon and oxygen isotopes as diagenetic and stratigraphic tools: surface and subsurface data, Barbados, West Indies. Geology, 5: 16-20.
Allan, J.R., Matthews, R.K., 1982. Isotope signatures associated with early meteoric diagenesis. Sedimentology, 29: 797-817.

Al-Ramadan, K., Dogan, A., Senalp, M., 2013. Sedimentology and diagenesis of the Miocene Nutaysh Member of the Burqan Formation in the Midyan Area, northwestern Saudi Arabia. Geological Quarterly, 57 (1): 165-174 
Banner, J., G. Hanson, 1990. Calculation of simultaneous isotopic and trace element variations during water-rock interaction with applications to carbonate diagenesis. Geochimica et Cosmochimica Acta, 54: 3123-3137.

Bathurst, R.G.C., 1975. Carbonate Sediments and Their Diagenesis. 2nd edition, Elsevier, New York.

Batt, L.S., Montańez, I.P., Isaacson, P., Pope, M.C., Butts., S.H. Ablplanalp, J., 2008. Multicarbonate component reconstruction of mid-Carboniferous (Chesterian) seawater $\delta^{13} \mathrm{C}$. Palaeogeography, Palaeoclimatology, Palaeoecology, 256: 298-318.

Bishop, J.W., Osleger, D.A., Montańez, I.P., Sumner, D.Y., 2014. Meteoric diagenesis and fluid-rock interaction in the Middle Permian Capitan backreef: Yates Formation, Slaughter Canyon, New Mexico. AAPG Bulletin, 98: 1495-1519.

Bosworth, W., Mcclay, K., 2001. Structural and stratigraphic evolution of the Gulf of Suez rift, Egypt: a synthesis. Mémoires du Muséum national d'histoire naturelle, 186: 567-606.

Brand, U., 2004. Carbon, oxygen and strontium isotopes in Paleozoic carbonate components: an evaluation of original seawater-chemistry proxies. Chemical Geology, 204: 23-44.

Brand, U., Veizer, J., 1980. Chemical diagenesis of a multicomponent carbonate system - 1: trace elements. Journal of Sedimentary Research, 50: 1219-12136.

Brand, U., Veizer, J., 1981. Chemical diagenesis of a multicomponent carbonate system -2 : stable isotopes. Journal of Sedimentary Research, 51: 987-997.

Clark, M.D., 1986. Explanatory Notes to the Geologic Map of the Al Bad' Quadrangle, sheet 28A, Kingdom of Saudi Arabia. Saudi Arabian Deputy Ministry for Mineral Resources Geoscience Map Series GM-81A, C, scale 1:250,000, with text, 46 p.

Dickson J.A.D, 1966. Carbonate identification and genesis as revealed by staining. Journal of Sedimentary Petrology, 36: 441-505.

Dickson, J.A.D., Kenter, J.A.M., 2014. Diagenetic evolution of selected parasequences across a carbonate platform: Late Paleozoic, Tengiz Reservoir, Kazakhstan. Journal of Sedimentary Research, 84: 664-693.

Fheed, A., Swierczewska, A. and Krzyżak, A., 2015. The isolated Wuchiapingian (Zechstein) Wielichowo Reef and its sedimentary and diagenetic evolution, SW Poland. Geological Quarterly, 59 (4): 762-780.

Gross, M.G., 1964. Variations in the ${ }^{18} \mathrm{O} /{ }^{16} \mathrm{O}$ and ${ }^{13} \mathrm{C} /{ }^{12} \mathrm{C}$ ratios of diagenetically altered limestones in the Bermuda Islands. Journal of Geology, 72: 170-194.

Heba, G., Prichonnet, G., El Albani, A., 2009. Meteoric diagenesis of Upper Cretaceous and Paleocene-Eocene shallow-water carbonates in the Kruja platform (Albania): geochemical evidence. Geologica Carpathica, 60: 165-179.

Hughes, G.W., Johnson, R.S., 2005. Lithostratigraphy of the Red Sea Region. GeoArabia, 10: 49-126.

Jadoul, F., Galli, M.T., 2008. The Hettangian shallow water carbonates after the Triassic/Jurassic biocalcification crisis: the Albenza Formation in the Western Southern Alps. Rivista Italiana di Paleontologia e Stratigrafia, 114: 453-470.

Koeshidayatullah, A., Al-Ramadan, K., Collier, R., Hughes, G.W., 2016. Variations in architecture and cyclicity in fault-bounded carbonate platforms: Early Miocene Red Sea Rift, NW Saudi Arabia. Marine and Petroleum Geology, 70: 77-92.

Land, L.S., Epstein, S., 1970. Late Pleistocene diagenesis and dolomitization, North Jamaica. Sedimentology, 14: 187-200.

Lohmann, K.C., 1988. Geochemical patterns of meteoric diagenetic systems and their application to studies of paleo- karst. In: Paleokarst (eds. N.P. James and P.W. Choquette): 58-80. Springer, Berlin.

Major, R.P., 2014. Early Meteoric Diagenesis and Porosity Preservation: Stratigraphic Traps in Carbonate Grainstones. Conference paper in International Petroleum Technology Conference, Kuala Lumpur, Malaysia, https://www.onepetro.org/download/conference-paper/IPTC-17924-MS?id=conference-paper\%2FIPTC-17924-MS

Melim, L.A., Westphal, H., Swart, P.K., Eberli, G.P., Munnecke, A., 2002. Questioning carbonate diagenetic paradigms: evidence from the Neogene of the Bahamas. Marine Geology, 185: 27-53.

Meyers, W.J., Lohmann, K.C., 1985. Isotope geochemistry of regionally extensive calcite cement zones and marine components in Mississippian limestones, New Mexico. SEPM Special Publication, 26: 223-239.

Morrow, D.W., Mayers, I.R., 1978. Simulation of limestone diagenesis: a model based on strontium depletion. Canadian Journal of Earth Science, 15: 376-396.

Rao, C.P., 1991. Geochemical difference between subtropical (Ordovician) temperate (Recent and Pleistocene) and subpolar (Permian) carbonates, Tasmania, Australia. Carbonates and Evaporites, 6: 83-106.

Ronchi, P., Jadoul, F., Ceriani, A., Di Giulio, A., Scotti, P., Ortenzi, A., Previde Massara, E., 2011. Multistage dolomitization and distribution of dolomitized bodies in Early Jurassic carbonate platforms (Southern Alps, Italy). Sedimentology, 58: 532-565.

Saoudi, A., Khalil, B., 1986. Distribution and Hydrocarbon Potentia of Nukhul Sediments in the Gulf of Suez. Proceedings of the Seventh Exploration Seminar, Cairo: 75-96.

Smalley, P.C., Bishop, P.K., Dickson, J.A.D., Emery, D., 1994. Water-rock interaction during meteoric flushing of a limestone: implications for porosity development in karstified petroleum reservoirs. Journal of Sedimentary Research, 64: 180-189.

Swart, P.K., 2015. The geochemistry of carbonate diagenesis: the past, present and future. Sedimentology, 62: 1233-1304.

Tubbs, R.E., Fouda, A.H., Afifi, A.M., Raterman, N.S., Hughes, G.W. Fadolalkarem, Y.K., 2014. Midyan Peninsula, northern Red Sea, Saudi Arabia: Seismic imaging and regional interpretation. GeoArabia, 19: 165-184.

Tucker, M.E., 1986. Formerly aragonitic limestones associated with tillites in the late Proterozoic of Death Valley, California. Journal of Sedimentary Petrology, 56: 818-830.

Tucker, M.E., Wright, V.P., 1990. Carbonate Sedimentology. Blackwell Scientific Publications.

Videtich, P.E., 1982. Origin, marine diagenesis, and early fresh-water diagenesis of limestones and dolomites (Tertiary-Recent): stable isotopic, electron microprobe, and petrographic studies. Ph.D. thesis, Providence, Rhode Island, Brown University.

Veizer, J., Demovic, R., 1974. Strontium as a tool in facies analysis. Journal of Sedimentary Petrology, 44: 93-115.

Whitaker, F.F., Paterson, R.J., Johnston, V.E., 2006. Meteoric diagenesis during sea-level lowstands: evidence from modern hydrochemical studies on northern Guam. Journal of Geochemical Exploration, 89: 420-423.

Winefield, P.R., Nelson, C.S., Hodder, A.P.W., 1996. Discriminating temperate carbonates and their diagenetic environments using bulk elemental geochemistry, a reconnaissance study based on New Zealand Cenozoic Limestone. Carbonates and Evaporites, 11: 19-31. 